\title{
EFEKTIFITAS HIDROGEN PEROKSIDA DALAM MEMBUNUH BAKTERI AIR ULTRA SCALER PADA DENTAL UNIT DI RSIGM SULTAN AGUNG SEMARANG
}

\author{
Laily Maghfira Noor Ridarsyah ${ }^{*}$ Djoko Priyanto**, Grahita Aditya**
}

\begin{abstract}
Keywords:

hydrogen peroxide, ultra scaler water, back flow

Background: Infection control is essential in dentristry. Many studies suggested an increase of bacteria in dental unit due to back flow from ultrasonic scaler. Previous study states that hydrogen peroxidein 3\% concentration may reduce the number of bacteria's colony of ultrasonic scaler water in RSIGM Sultan Agung Semarang significantly. Purpose: The aim of this study was to determine the effectiveness of hydrogen peroxide to kill bacteria of ultrasonic scaler water on dental unit in RSIGM Sultan Agung Semarang. Method: The type of research used in the study is quasy experimental with pretest-posttest design. The sample used in this study is 15 dental units which were divided into 3 groups group I $2 \%$ hydrogen peroxide, group II $4.5 \%$ hydrogen peroxide, and group III $6 \%$ hydrogen peroxide and than flow it on ultrasonic scaler water and check the bakteria before and after experiment. Result: Based on the results of Wilcoxon test the comparison before and after at the three groups obtained the results of significance is less than 0.05 . It can be concluded that hydrogen peroxide effectively kills bacteria of ultrasonic scaler water on dental unit in RSIGM Sultan Agung Semarang. Conclusion: From the results it can be concluded that the percentage of hydrogen peroxide which can cause all organisms die without disturbing the patient's health is at $4.5 \%$ and $6 \%$ concentration.
\end{abstract}

\section{PENDAHULUAN}

Praktek kesehatan yang baik memerlukan pengendalian infeksi yang efektif, tidak terkecuali dibidang kesehatan gigi dan mulut. Banyak hasil penelitian yang menyatakan adanya peningkatan bakteri pada dental unit yang digunakan dokter gigi, dimana bakteri tersebut dapat mengkontaminasi dental unit sehingga dapat menjadi ancaman kesehatan masyarakat atau pasien ${ }^{1}$. Dental unit merupakan seperangkat unit kursi yang mengandung sistem terpadu yang dialiri oleh air dan menyediakan instrument serta layanan berbagai prosedur gigi. Telah dilakukan penelitian sebelumnya bahwa Hidrogen peroksida, kaporit, dan pereaksi fenton membuktikan hidrogen peroksida adalah disinfeksi yang paling efektif ${ }^{3}$. Penelitian 40 tahun terakhir menunjukkan tingginya jumlah mikroorganisme terutama bakteri aerob gram negatif yang mencemari DUWL (dental unit waterline) ${ }^{4,5}$. Mikroorganisme pada air dental unit bersumber dari cairan mulut pasien, biofilm dan mikroorganisme yang berasal dari air (waterborne microorganism).

Hidrogen peroksida memiliki sifat oksidator yang sangat kuat yang digunakan sebagai bahan pemutih dan sebagai desinfektan. Dalam dunia kesehatan, hidrogen peroksida sering digunakan sebagai disinfektan karena tidak meninggalkan residu yang berbahaya. Untuk mempelajari efek dari berbagai konsentrasi hidrogen peroksida terhadap biofilm dalam mengendalikan organisme dalam system air dental unit, dan untuk mengetahui efek dari konsentrasi $2 \%, 4,5 \%$, dan $6 \%$ hidrogen peroksida pada penghapusan biofilm dan senyawa anorganik dalam dental unit ${ }^{6}$.

Hasil penelitian lain diperoleh hasil bahwa hidrogen peroksida pada konsentrasi

*Program Pendidikan Dokter Gigi Fakultas Kedokteran Gigi Unissula Semarang, ** Staff Pengajar Fakultas

Kedokteran Gigi Universitas Islam Sultan Agung Semarang

Korespondensi : fiaridarsyah@yahoo.com 
3\% merupakan konsentrasi yang aman dan minimal menghilangkan biofilm, konsentrasi $4,5 \%$ merupakan rata-rata konsentrasi dari konsentrasi $2 \%$ dan $6 \%$ untuk dicari keefektifannya yang aman digunakan untuk manusia. Dan konsentrasi 6\% merupakan konsentrasi yang baik untuk disinfeksi, tetapi masih terlalu tinggi dan memungkinkan bersifat korosif 6 .

Dari latar belakang yang telah diuraikan diatas peneliti ingin melanjutkan penelitian lebih lanjut terhadap efektifitas hidrogen peroksida pada air dental unit untuk membunuh bakteri, namun dalam konsentrasi yang berbeda dari penelitian yang sebelumnya. Tujuan dari penelitian ini adalah untuk mengetahui efektifitas pemberian hidrogen peroksida dalam membunuh bakteri air ultra scaler pada dental unit di RSIGM Sultan Agung Semarang. Hasil penelitian ini diharapkan dapat memberikan tambahan pengetahuan bagi peneliti maupun pembaca tentang efektifitas hidrogen peroksida dalam membunuh mikroorganisme pada dental unit yang ada di RSIGM Sultan Agung Semarang.

\section{METODE PENELITIAN}

Rancangan penelitian yang digunakan adalah quasy eksperimental jenis pretest- postest design, yaitu suatu penelitian yang diberikan intervensi terhadap variabel bebasnya untuk mengetahui pengaruh yang timbul terhadap variabel yang lain. Jenis penelitian ini tidak menggunakan kelompok kontrol ${ }^{7}$.

Alat yang digunakan dalam penelitian ini adalah inkubator pipet steril, tabung reaksi, cawan, botol sampel steril, autoklaf, reservoir steril, selang dental unit. Adapun bahan yang digunakan dalam penelitian ini adalah air ultrasonic scaler, $\mathrm{NaCl}$ (pengencer), media nutrient agar cair, hidrogen peroksida $\left(\mathrm{H}_{2} \mathrm{O}_{2}\right)$. Prosedur dalam penelitian ini yaitu sampel diambil dari air ultrasonic scaler yang lalu ditampung pada botol kaca yang sudah dicuci dan dikeringkan serta dilakukan sterilisasi dengan menggunakan autoklaf; operator menggunakan handscoen, kemudian membuka tutup botol dan sampel air diambil; sampel air diambil sebanyak 2 kali; Sampel pertama diambil pada saluran air ultrasonic scaler tanpa diberi perlakuan dengan hidrogen peroksida $2 \%, 4,5 \%$ dan $6 \%$ sebanyak $60 \mathrm{ml}$; Sampel kedua diambil dengan bahan desinfektan hidrogen peroksida $2 \%, 4,5 \%$ dan $6 \%$; Setelah sampel air diambil, buat pengenceran dengan garam fisiologis steril $(\mathrm{NaCl})$ : mulai tanpa pengenceran, pengenceran $10^{-1}$, pengenceran $10^{-2}$ kemudian pengenceran $10^{-3}$.

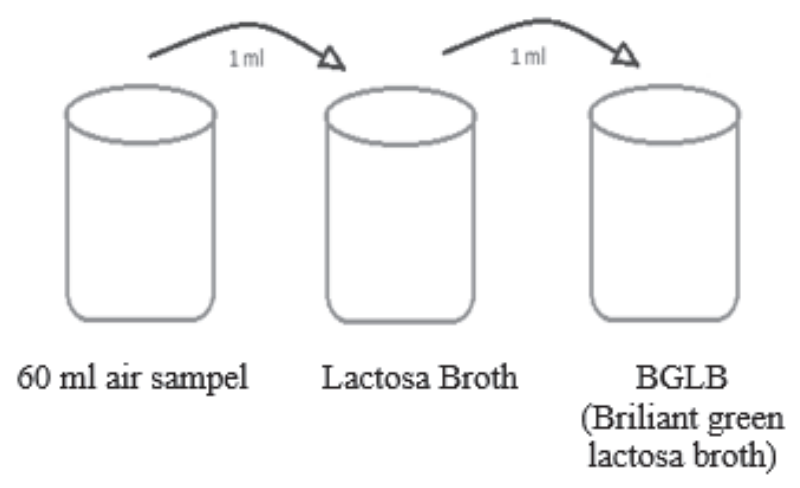

Gambar 1 Cara melakukan pengenceran 
Dengan metode MPN (Most Probable Number) air sampel diambil dan dimasukkan pada tabung reaksi yang berisi lactosa broth (merah) untuk mengetahui adanya bakteri yang memfermentasi lactosa. Bila warna merah pada tabung berubah menjadi kuning dan berisi gas artinya positif $(+)$ terdapat bakteri yang mampu memfermentasi lactosa. Jika hasilnya positif kemudian pindahkan pada tabung reaksi yang berisi BGLB (briliant green lactosa broth) untuk menseleksi bakteri coliform, lalu diinkubasi dengan suhu 370 C. Jika warna berubah menjadi keruh dan terdapat gas artinya positif $(+)$ mengandung bakteri coliform.

\section{HASIL PENELITIAN}

Pada penelitian ini berdasarkan tabel rata-rata presentase zona efektifitas kelompok perlakuan dalam membunuh bakteri ultra scaler didapatkan hasil sebagai berikut :

Tabel 1. Rata - rata persentase zona efektifitas hidrogen peroksida dalam kelompok perlakuan dalam membunuh bakteri ultra scaler

\begin{tabular}{lll}
\hline Kelompok & Rata-rata \% & Min \pm Max \\
\hline Kelompok I & 25.85 & $0.00 \pm 60.00$ \\
Kelompok II & 100 & - \\
Kelompok III & 100 & - \\
\hline
\end{tabular}

Dari data diatas menunjukkan bahwa pada kelompok I yang diberi hidrogen peroksida konsentrasi $2 \%$ jumlah bakteri yang terbunuh sebanyak $25,85 \%$, sedangkan pada kelompok II yang diberi hydrogen peroksida konsentrasi $4,5 \%$ dan kelompok III yang diberi hidrogen peroksida konsentrasi $6 \%$ dapat membunuh bakteri $100 \%$.
Perbandingan sebelum dan sesudah di dalam kelompok sampel menggunakan uji alternatif Wilcoxon, karena syarat uji parametrik paired t-test -tidak dapat terpenuhi. Hasil Uji Wilcoxon sebagai berikut:

Tabel 2. Hasil Uji Wilcoxon

\begin{tabular}{|c|c|c|}
\hline $\begin{array}{l}\text { Perbandingan } \\
\text { sebelum-sesudah }\end{array}$ & $\begin{array}{l}P \\
\text { value }\end{array}$ & Keterangan \\
\hline Kelompok I & 0.017 & Berbeda signifikan \\
\hline Kelompok II & 0.004 & Berbeda signifikan \\
\hline Kelompok III & 0.005 & Berbeda signifikan \\
\hline
\end{tabular}

Dari hasil uji wilcoxon diatas menunjukan bahwa ketiga kelompok menunjukan $P$-Value kurang dari 0,05 , yang berarti ada perbedaan signifikan anatara sebelum dan sesudah pemberian hidrogen peroksida konsentrasi $2 \%$; $4,5 \%$; dan $6 \%$.

Untuk membandingkan pengaruh masing-masing konsentrasi dilakukan uji alternatif Kruskal Wallis, karena uji normalitas menggunakan Shapiro-Wilk diketahui bahwa seluruh kelompok sampel tidak berdistribusi normal serta hasil uji homogenitas dengan Levene Test menunjukan data tidak homogen, sehingga tidak dapat memenuhi syarat uji parametric Oneway Anova. Hasil pengujian data pada ketiga kelompok sebagai berikut:

Tabel 3 Hasil Uji Kruskal-Wallis perbedaan efektifitas Hidrogen Peroksida dalam membunuh Bakteri Ultra Scaler

\begin{tabular}{lcl}
\hline Kelompok & P value & Keterangan \\
\hline Kelompok I & & \\
Kelompok II & 0.001 & Berbeda signifikan \\
Kelompok III & & \\
\hline
\end{tabular}

Tabel 4 Hasil uji Mann-Whitney

\begin{tabular}{llll}
\hline \multicolumn{2}{c}{ Kelompok } & Sig. & \multicolumn{1}{c}{ Ket. } \\
\hline \multirow{2}{*}{ Kelompok I } & Kelompok II & 0.005 & Berbeda Bermakna \\
Kelompok II & Kelompok III & 0.005 & Berbeda Bermakna \\
\hline
\end{tabular}


Berdasarkan hasil uji Kruskal-Wallis diperoleh nilai $p$ sebesar $0.001 \quad(<0.05)$ yang berarti bahwa ada perbedaan tingkat efektifitas membunuh bakteri yang bermakna minimal antara 2 kelompok / konsentrasi yang berbeda.

Berdasarkan hasil uji Mann-Whitney diatas, perbandingan kelompok I terhadap kelompok II dan kelompok III diperoleh nilai signifikansi sebesar $0.005<0.05$ yang berarti bahwa ada perbedaan efektifitas yang signifikan. Sedangkan perbandingan kelompok II terhadap kelompok III diperoleh signifikansi sebesar $1.000>0.05$ yang berarti tidak ada perbedaan efektifitas yang signifikan antara kedua kelompok.

\section{DISKUSI}

Dari hasil penelitian kelompok I, II, dan III menunjukan perubahan jumlah bakteri yang mampu terbunuh pada dental unit. Data juga menunjukkan adanya perubahan yang signifikan pada jumlah bakteri yang terdapat di dental unit dengan pemberian hidrogen peroksida dengan konsentrasi $4,5 \%$ dan $6 \%$. Dari hasil uji Wilcoxon dari ketiga pasangan baik pada kelompok I, II, dan III didapatkan nilai signifikansi kurang dari 0,005 yang berarti bahwa terdapat perbedaan yang signifikan antara sebelum dan sesudah perlakuan pada ketiga kelompok tersebut.

Berdasarkan hasil uji Kruskal-Wallis diperoleh nilai $p$ value sebesar $0.001 \quad(<0,05)$ yang berarti bahwa ada perbedaan tingkat efektifitas membunuh bakteri yang bermakna minimal antara 2 kelompok atau konsentrasi yang berbeda, oleh sebab itu dapat dilihat dari kelompok I dan II atau kelompok I dan III, karena kelompok II dan III memiliki nilai yang sama.

Dari penelitian yang telah dilakukan oleh peneliti dengan pengambilan air ultrasonic scaler ditemukan masih terdapat bakteri Pseudomonas aeruginosa, Klebsiella pneumoniae, dan Serratia marcesens. Setelah perlakuan hidrogen peroksida pada kelompok I dengan konsentrasi $2 \%$. Pada kelompok II dan III pasca perlakuan dengan konsentrasi $4,5 \%$ dan
6\% sudah tidak terdapat bakteri Pseudomonas aeruginosa, Klebsiella pneumoniae, dan serratia marcesens ${ }^{8}$.

Pseudomonas aeruginosa mempunyai karakteristik menempelkan diri pada alat medis kedokteran dan dapat bertahan hidup lebih lama dari bakteri lain dipermukaan alat, itu sebabnya pseudomonas aeruginosa sukar untuk dibunuh dengan konsentreasi hidrogen peroksida yang rendah. Hidrogen peroksida $3 \%$ memiliki keterbatasan dalam membunuh bakteri ${ }^{8}$. pernyataan tersebut sejalan dengan penelitian ini bahwa hidrogenperoksida $2 \%$ kurang efektif dalam membunuh bakteri.

Hasil penelitian ini didukung dengan penelitian sebelumnya yang menyatakan bahwa konsentrasi hidrogen peroksida $2 \%$ hanya dapat mengontrol lapisan biofilm yang didalamnya terdapat bakteri, tetapi kurang efektif dalam membunuh semua bakteri. Penelitian tersebut menyatakan bahwa hidrogen peroksida dengan konsentrasi $6 \%$ efektif dalam membunuh bakteri ${ }^{6}$.

Dalam studi, 6\% hidrogen peroksida lebih efektif dalam disinfeksi daripada glutaraldehid solusi $2 \%{ }^{9}$.

\section{KESIMPULAN}

1. Persentase hidrogen peroksida agar semua organisme dapat mati tanpa mengganggu kesehatan pasien adalah pada konsentrasi $4,5 \%$.

2. Jumlah mikroorganisme pada kelompok I, II, dan III sebelum diberi hidrogen peroksida $2 \%, 4,5 \%$, dan $6 \%$ yaitu berjumlah $3,22 / 100$ $\mathrm{ml}, 2,96 / 100 \mathrm{ml}$, dan 3,12/100 ml bakteri.

3. Jumlah mikroorganisme pada dental unit setelah diberi hidrogen peroksida $2 \%$, $4,5 \%$, dan $6 \%$ menjadi $2,04 / 100 \mathrm{ml}, 0 / 100$ $\mathrm{ml}$, dan 0/100 ml.

4. Perubahan jumlah mikroorganisme pada dental unit sebelum dan sesudah pemberian hidrogen peroksida pada konsentrasi $2 \%$ hanya dapat mengurangi jumlah bakteri, sedangkan pada konsentrasi $4,5 \%$ dan $6 \%$ dapat membunuh semua bakteri. 


\section{DAFTAR PUSTAKA}

1. Phankhurst, Carolina L., Risk Assessment of Dental Unit Waterline Contamination, Primary Dental Care (2003)

2. O'Donnell, Mary J., Boyle, Maria A., Russell, Ronnie J., Coleman, David C. Management of dental unit waterline biofilms in the 21st century. Future Microbiol (2011) dalam Kusuma, Risky H.P., Pengaruh Hidrogen Peroksida Terhadap Jumlah Bakteri Air Ultrasonic Scaler Pada Dental Unit Rsigm Sultan Agung Semarang (2014)

3. Setiawan D, Sibarani S, Suprihatin I.E., Perbandingan Efektifitas Disinfektan Kaporit Hidrogen Peroksida dan Pereaksi Fenton, Indonesian E-Journal of Applied Chemistry, Vol1, No2 (2013)

4. Blake GC. The incidence and control of bacterial infection in dental spray reservoirs. Brit Dent $\mathrm{J}$. 115:413-416 (1963)

5. Charles M. Belting dan Philip J. Spjut, Effect of highspeed periodontal Instruments on the Root Surface during Subgingival Calculus Removal. Vol 69, Issue 5, 578-584 (1964)

6. Lin Shih Ming, Svoboda Kathy K.H, Giletto A, Seibert
$J$, Puttaiah R., Effects of Hydrogen Peroxide on Dental Unit Biofilm and Treatment Water Contamination, European Journal of Dentistry, Vol5 (2001)

7. Sastroasmoro, S dan Ismael. Dasar-dasar metodologi penelitian klinis. Edisi 2. Jakarta: CV. Agung Seto. (2006)

8. Agustin, D.W., Perbedaan khasiat antibacteri bahan irigasi antara hidrogen peroksida 3\% dan infusum daun sirih 20\% terhadap bakteri mix. Maj.Ked.Gigi. (Dent.J.),vol.38,No.1,h.45:47 (2005)

9. Rutala W.A.,Weber D.J., Guideline for Disinfection and Sterilization in Healthcare Facilities, University of North Carolina, Chapel Hill, (2008) 